\title{
The Requirements of the International Solidarity for a Sustainable Development in Developing Countries
}

\author{
Prof Alphonse NKONGOLO Mulami K.*
}

\begin{abstract}
The question is how to realize under what conditions international solidarity could be acceptable and could contribute to the truly sustainable development of the countries of the third world. What are the requirements (ethical, scientific, environmental ...) of a truly sustainable development? It will be straightforward to demonstrate that any international solidarity of a project (i.e. any multilateral or bilateral financing, etc.) that does not provide a chain of values in its execution, evidencing a clear theory of change, this international solidarity will be declared ineffective, and therefore rejected by Third World countries, since it does not guarantee in any way sustainable development, but is only capable of favoring all other evils (corruption, corruption, etc.). ...) that Dambisa Moya had to stigmatize in a book "Help fatale".
\end{abstract}

Keywords: International solidarity. Sustainable development. Developing countries

\section{Introduction}

To develop durably is a fundamental aspiration for everyone. By durable development we must understand a continuous amelioration process of human conditions during our existence on the earth for a time estimated to be long enough by and for humans concerned in given space thanks to the intellectual creativity/or ingenuity. It is a development taking in account the resolution of the today's problem without compromising the futures generations". Then, it consists more in the "wellbeing" than the "well-getting".

The robust development is a new approach of the general interest aiming at assuring long-lasting action of our societies, our ecosystem and also our economy. It can also be considered as a unique opportunity to rethink our ways. It is a lever of innovation which lies on three dimensions which are: environmental, social and economic worth living, attractable, long-lasting and equitable. In this way, it can be measured through these four indicators: the knowledge, the capacity, the duty and having. By knowledge, we should understand the perception and skills in what we have to do, how we should live and how to address technologically, scientifically, industrially, environmentally, economically ... and also by "capacity", as indicator we understand the right and freedom to act, to decide, to transform and be transformed. In the third position, by "duty" we should understand the deep obligation such as the responsibility to survive, the responsibility to produce and the responsibility for union; and to finish, by "to have" we understand the sense of possessing and how to use profitably the housing, necessary equipment and this in a way that it can help produce an income to ensure the minimal living standard.

${ }^{1}$ Cfr. www.futura-sciences.com/definitions 
So understood, such a development is and stays a big permanent challenge for every man of all generations and elsewhere all around the earth planet. This is why, through the humanity history there were many paths of solutions: strategies, methods, visions, etc. were conceived so as to respond this challenge target of the mankind to attain the needed results. Meanwhile, the action is that even all these paths of solutions, a real and fix development becomes a utopia, an ideal never and difficult to reach.

If we have to understand why all the man's efforts did not contributed to attain the objectives, it is necessary to sort the different strategies of development experienced up today and analyze them so as to find a way to measure each of them, their level of efficiency. We should note then that the different strategies elaborated during the past generations may be regrouped in three main tendencies ${ }^{22}$

\section{Determinist and decreasing tendency.}

This tendency assures that the solution to the problem of the robust development of the countries called "countries in development ways" 33 must necessarily pass through international solidarity so called "Help to the development". It is so to say, a tendency or determinist vision, pyramidal and decreasing tendency of the development; because decided upstairs. It is then, a miracle and providential vision because it comes without direct and substantial implication of the beneficiaries. A magic solution because given in a way of ready-to-take. A "paternalist vision" because making the beneficiaries the eternal "receivers" instead of making them "protagonists" of their own development; $a$ determinist and linear vision of development because resulting from a sort of "copy-paste" in which it is considered that the under-developed countries have nothing to invent, they should simply take what is already invented or conceived abroad and apply it in their context so that the development starts "immediately" in these beneficiary countries. May we think, for example that, a domestic contractor whose activity is hair-cut-room has no need to invent a new pair of scissors because it already exists and so his task is already facilitated? Such a vision can never stimulate and favor the creativity or self-initiative imagination in the beneficiary intelligence. On the contrary, it paralyzes kills and buries ready-made predispositions in every man.

It is this determinist and decreasing solution...we doubt that characterized and characterizes once again certain politics called "politics to the Development aid". In fact, we must recognize that these politics of aid to the development did something considerable in the history of the humanity since amongst them the Marshall Plan, the one conceived and applied at the tomorrow of the Second World War by the winner countries to sustain the loser countries. Meanwhile, as all medals has a second face, there is no doubt to recognize that all these aid politically, presents and presents again today many merits that have dangerous limits for an authentic and robust development only if they are applied

\footnotetext{
${ }^{2}$ Read an excerpt of our doctoral thesis: Efficiency and fitness of local of development in globalized context, Rome, PUG, 2014.

3 To consider the so-called developing countries we think of theme to be in perpetual way of underdevelopment. The reasons may be many ones. But the responsibility of the international in this perpetual regression is not to be neglected. This way our contribution at this conference is focused on this aid.
} 
as a ready-to-bear in the context of the developing countries. Or, a perpetually assisted people cannot truly and durably develop it. The case of Democratic Republic of the Congo is an indisputable one. During many years in the past, the country received milliard of dollars today considered as a public debt ${ }^{44}$, which permit to render the poorest to become more poorer, forcing them to live under the weight of the debt and hunger, when these two are considered to be the weapons of mass destruction evoked in the Empire of shame by Jean Ziegler who writes : "we assist to a formidable movement of re-foundation of the world, to an adjusted shaping of the people from south hemisphere by the big transcontinental societies. The two mass destruction weapons are the work of: the debt and the hunger. From debts many states quit their sovereignty; by the running hunger, people disappear and reject their freedom. Yes, it's good for the shame empire which has secretly established itself on the planet5. It is then, a vision for which the interest is to see the third-world under-develop continually and all days depending in all points of view. So, as it is said,: " the misfortune of the ones makes the fortune for the others".

This decreasing vision of the development makes and still makes of the International Aid its mark, its main battle tool, and a weapon without which it'll cease to exist and then dry of sense. This aid has three forms so to say (multinational aid; bilateral aid; and charitable aid) remains a concept and a fundamental element in determining the international cooperation. Or so often, each of all these forms contains a destructive virus and has limits which cannot secure automatically the fix or durable development hoped and awaited by all.

\subsection{Multilateral Aid}

It is that one brought by the International Non-Governmental Organizations (INGO). Generally speaking, these INGO make a certain experiences in some of their own countries and in a specific context, and reflect them in the so-called developing countries. When they arrive in these countries they do some pilot operations in a précised village while a big portion of the country is marginalized. So to say, out of the normal sphere of this operation. It is often contaminated of the lack of permissibility arranged according to the awaited results and financial means corresponding, weak traceability on its way to attain the results and the used means as well as the lack of follow-up and evaluation for periodical performance and regular.

A specific case is one of all these funding around the running projects of the type "schools and cleaned villages" 65 . In fact, it is certain that such targeted aid can bring a durable development because it is very limited in time and space. It cannot cover all the sectors and the need of the beneficiaries of the whole country.

\footnotetext{
4 There exists a difference between outer debt and public debt. The first represents the totality of the borrowings from economical agents towards the foreign lenders. The second(public debt), is states' debt. It represents the totality of the states' engagements (central administration, local, social security) for a fixed date. It is a flux of the resources borrowed to be paid back by the state on that fixed date. See www.glossaire-international.com.

5 ZIEGLER, J. , the Empire of shame, pp. 91-161.

${ }^{6}$ In DRC for example the big funding from organizations such as (DIFIDE, Unicef,...) invested in what we are used to call School and Cleaned Villages. But some time later when you pass there is nothing but visibility panels in the growing grass.
} 


\subsection{Bilateral Aid}

This a cruel form of existing aid, the murdering one for the beneficiary countries, simply because it an aid which has brought the notion of profit. There is nothing for nothing when it is given. No gratefulness. The donor gives because he sees a profit when the beneficiary blinded by the profound misery in which he lives, believes in as the gift from the sky or gift as such there's none.

Here, there is not a help in its true sense, but a sort forced aid because it is a sort of aid not solicited by the beneficiary country. For illustration, let us the case of Aid to an agricultural project. The financial partner gives money pretending to sustain the project, but in fact, it is a way for him to find a market for the products from his own country. Then, there is a hypocrite calculation of profit that cannot be discovered openly by the beneficiary. It is then a sort of a useless help accompanied by a section of devastation for which Dambisa Moya ${ }^{7}$. This led singularly to the corruption by the leaders who are the true first beneficiaries and managers. The small people, instead of being the main beneficiaries, are totally excluded in the sphere of these aids.

It is then clear that the developing countries cannot count on such an aid to develop robustly. It is cruel as it isn't planified the employments only in the countries the help is from. It becomes then as a tool used to impose some politics and so often in a total disdain of traditions and customs of the milieu as well as the beliefs of the people to be helped. For the donors it seems that there is a sort of anticipated idea that there is no capacity in the countries where the aid is sent. The donor brings not only the funding but the so-called technicians and then become a Technical and Financial Partner (TFP). According to his expertise and skill, he works in a way that one invested dollar or given him makes four times a profit. And in this way, this apparent aid, only the donors' countries get savagely richer instead of the helped countries.

With such a sort of aid, we can affirm that on the international plan, there is no support as such; there are only profits. There is no authentic aid, there's only assistance and support so as to divide the retributions. Briefly, all the international aid of the genre brings the connections; it is directly or indirectly a tied help or aid to help tie. The faith of international aid has given birth to the apparition of many NGOs (local and international) which favored the money-whiteness. Such an aid cannot bring to a robust development. On the contrary, it paralyzes, and brings up many bad habits which damage the quality of development and the well-being to which we aspire.

\subsection{Charitable Aid}

In the register book of the International Aid, we must mention this other form of aid called "Charitable Aid". It is this form of aid that some countries, organizations, and some philanthropic persons brings to certain countries and generally in case of natural disasters, murdering conflicts and wars,...this is called emergency aid. An aid brought on time which doesn't last-long. Its punctuality and fewness character so often create problems.

In fact, for a population which benefits such an aid, it is absolutely necessary to pass from emergency projects to the robust development projects. If this passage isn't done, the robust development we aspire cannot have support such a form of aid because we find ourselves in a system where the misfortune of some makes the fortune of the 
others. As we know, there is sometimes in today's world some entertained conflicts by those who gain profit from them. The given helps do not reach at $100 \%$ to the beneficiary countries. The donors or the NGOs which constitute the transmission channels of this aid, easily become the tourists in development in the ground of the beneficiary countries. As we said, it is a punctual aid when the development awaited must be robust.

\subsection{Permanent traps of the Aid to the development}

From the analysis of these three forms of the Aid to the development, there are some traps:

- The financial volume of this aid is often small to compensate the world inequality dynamics. Its official destination is dark, not controlled, full of contradictions. Its lack of success is often presented as a proof that the south countries are "Pits without a basis" which swallows indefinitely the help from the West. In reality, the help from the West is a political and economic profit engine for the Western powers. ${ }^{86}$

- This useless aid seems to be a bridge or an instrument to serve to the recolonization. It submits the nations and their leaders.

- It is a help which develops submission: this aid has led to the perpetual submission and childish of all of the states' system (political, economic, social,...) of the helped country. It increases the sense of inferiority of these countries to the donors countries to the point at which the helped countries terminate by interiorizing this sense of inferiority, so as to mean, as it is often said: the hand which gives is above the one which receives. It is then the whole dignity of a people which is in danger.

- It is an aid which conditions: it is an aid which has conditions able to ridicule the values, the beliefs, the convictions of the helped people. It is a help which ties, imprisons, and sometimes breaks the dignity of the beneficiary.

\subsection{Conditions to make this aid profitable}

The international aid is and will be always necessary. At certain conditions it may well contribute to the awaited development. The under-developed country should and must count on such an aid necessarily, but at some conditions. Globally, these conditions stand as follows:

- First, the respect of the locally conceived priorities,

- Second, the placement of its financial input in a common basket so that the beneficiaries themselves are able do whatever they want to. This will permit the donor countries and organizations to stop development tourism on the ground of the helped countries. This means that all sort of help brought in these countries should prove its capacity to bring or to conduct the values chains. By values chains, we mean the chain able to bring an additional value which takes in account, analyzes, and reinforces vertical and horizontal liaisons between development actors. The only one able to analyze and appreciate in a right way the business milieu environment to be developed; which reinforces the relations between the milieu services to support, which detect the real winners in the chain and analyze the real technical needs and financial support; the chain

8 Cfr to whom the international aid profits? General information - March 2008, p. 23. 
which favor the "Go-Green" approach, the one which leads the community to manage its environment, to work on the question related to his own environment; a chain which develops the Accelerated Method of Participative Research "AMPR"; a value chain which leads to a true theory of change to mean a sort of essential action plan. We must then reach a theory which can upset many tendencies and increase the luck to a success: 1. Remember Mahatma Gandhi's thought who repeatedly said: «All that you think to do for me without me, you do it against me",

2. Excite the concerned population's participation in its own development, in his own milieu and at its own rhythm; because everyone must become an actor of his own development,

3. Rectify the gravity, reduce the obstacles, sustain the impulsion,

4. Evaluate periodically the routing,

5. Never abdicate.

This is what the Paris declaration ${ }^{97} \mathrm{su}$ mmarized in five well-conceived principles, but requiring to be traduced in acts as soon as possible. These are: Appropriation principle, alignment principle, harmonization principle, management principle focused on the results, Self-responsibility principle; and then it can simply be useful and acceptable.

\section{Ascendant tendency of development}

In fact, if for some people, the solution to the question of development must forcedly pass by the international solidarity, on the contrary other opinion sustain that " $a$ true development must start from the basis" as it is for a root of a tree; because in fact, we cannot pretend to develop a poor without his own participation from the conception of the project which is in his favor up to the evaluation passing by its realization.

For those of this tendency, the development must be inductive, ascendant, accidental, contextual, locally conceived, depending on a group of factors which must imperatively be taken in account according to the analysis of SWOT ${ }^{10}$. It is particularly the territorial potentialities, customs and traditions, territorial analysis of the vital needs of the protagonists by the protagonists themselves; the territorial role of the state, Civil society, the oppression groups and some other credible structures existing on the ground.

\section{The right middle tendency}

Facing the challenge of the robust development, there is a third tendency which is tracing itself and seems to be prominent. This is the right middle tendency at which we subscribe.

As a proof : let's take an example of a country which has received many helps changing nothing but simply increasing the outer debt and rendering more poorer its inhabitants as noticed here above. More other, if visibly, "the ascendant vision" compared to the decreasing vision, may be the best for some respects, it is not real that at some time that the efforts for development without assistance be an efficient and active solution. Consequently, our point of view, preferably is the combination of the two visions (the right middle one) as such we think of to bear the secret of a durable and true 9 See the Paris declaration on the efficiency of the development aid. Appropriation, harmonization,
alignment, results and mutual responsibility in https//www.oecd.org/cad/efficacité 
development; because we think it conceives a development vision able to conjugate harmonically the two antagonistic poles openly.

In fact, the development by international aid which binds the population of the countries called under-developed ones is western and westernized that it cannot global and then globally applied at every time and everywhere without creating some problems due to the adaptation.

The right middle tendency makes that the good leadership be favored by those who helps, and be applied by those who are helped. This implies that the helped countries might be convinced of their nationalism because if there's no discipline (small democratic autocracy) there's nothing going on in the helped countries.

\section{Conclusion}

The aid to the development known through moments since more than 60 years of universal declaration of the Human rights ${ }^{1}$ of the man corresponding to the existence of the United Nations, has provoked many problems for which there is no solutions as such. We figure out that there is no real contribution to the efficient and durable development of the underdeveloped countries today called "developing countries". So, the robust development to the service for which this help is pretended to be remains simply an illusion very far to reach every time we get nearer. This has then brought at a point that we believe that the durable development has conditions which must be fulfilled before we effectively attain it. In this way, condition for this aid to be useful deep reforms must be undertaken in the administration and justice plans. It also needs that those executing this aid be trained. At finish, it needs that there is an association in the work between political leadership, the critical mass and local responsible. If not, the countries called developing countries will remain eternally as such.

\section{References}

A qui profite l'Aide au développement ?, les renseignements généraux - mars 2008.

M.BETTATI, et ali, La Déclaration universelle des droits de l'homme, Nouvelle édition, Paris, Gallimard, 1988.

DAMBISA MOYO, L'Aide fatale. Les ravages d'une aide inutile et de nouvelles solutions pour l'Afrique, Préface de Niall erguson, JCLattès, 2009.

J. Ziegler, L'empire de la honte, Préface de l'Auteur, Paris, Fayard, 2005.

A.M. Nkongolo, L'efficacité et l'efficience des stratégies locales du développement en contexte globalisé, Extrait de thèse de doctorat, Rome, PUG, 2014.

Le développement durable tel que défini dans www.fatura-sciences.com/définitions, consulté le 15 juin 2017.

OCDE, Déclaration de Paris et le Programme d'action d'Accra consulté sur le www.oecd.org/cad/efficacité, le 15 juin 2017.

Dette extérieure et dette publique dans www.glossaire-international.com consulté le 15 juin 2017. 